\title{
Ensino Comercial e sua verticalização no Brasil: origens e história
}

\author{
Commercial Education and its verticalization in Brazil: origins and history \\ Educación Comercial y su verticalización en Brasil: orígenes e historia
}

Recebido: 06/09/2021 | Revisado: 20/09/2021 | Aceito: 27/09/2021 | Publicado: 28/09/2021

Ana Lúcia Araújo Borges
ORCID: https://orcid.org/0000-0002-9872-6373
Instituto Federal de Educação, Ciência e Tecnologia do Triângulo Mineiro, Brasil
E-mail: analuciaborges@iftm.edu.br
Luciano Marcos Curi
ORCID: https://orcid.org/0000-0001-7309-0578
E-mail: lucianocuri@iftm.edu.br
Wenstituto Federal de Educação Ciência e Tecnologia do Triângulo Mineiro, Brasil
Wenceslau Gonçalves Neto
ORCID: https://orcid.org/0000-0002-4374-0311
Universidade de Uberaba, Brasil
Universidade Federal de Uberlândia, Brasil
E-mail: wenceslau@ @ufu.br

\begin{abstract}
Resumo
A trajetória histórica do ensino em Ciências Contábeis, em Ciências Econômicas e em Administração no Brasil nos remete aos primórdios do Ensino Comercial no País, o qual foi o antecessor histórico dos três cursos mencionados. Nesta perspectiva, o objetivo deste artigo é apresentar a origem e a história do Ensino Comercial, para que possamos compreender melhor o processo de (trans)formação do Ensino Comercial e sua relação com o surgimento de cursos superiores de Contábeis, Economia e Administração ao longo do século XX. Para tanto, mostraremos a origem e os acontecimentos mais relevantes do Ensino Comercial nos seguintes períodos: a) Brasil Império b) primeiro período da Era Vargas, c) Governo Ditatorial de Getúlio Vargas, também conhecido como Estado Novo e d) redemocratização do Brasil, também conhecido como Segunda República. Enquanto aspectos metodológicos, esta pesquisa se classifica em relação à sua natureza como básica; de abordagem qualitativa. Em relação aos objetivos é descritiva e o procedimento técnico utilizado foi pesquisa bibliográfica e documental. Nos resultados desta revisão bibliográfica apresentamos a relevância da compreensão da história dos cursos e disciplinas escolares, em especial, do Ensino Comercial, em seus processos históricos de gênese, consolidação e inserção na história das instituições escolares.
\end{abstract}

Palavras-chave: Ensino comercial; Ensino técnico; Educação superior; Ensino; Ciências contábeis; Ciências econômicas; Administração.

\begin{abstract}
The historical trajectory of teaching in Accounting Sciences, Economic Sciences and Administration in Brazil takes us back to the beginnings of Commercial Education in the country, which was the historical predecessor of the three courses mentioned. In this perspective, the purpose of this article is to present the origin and history of Business Education, so that we can better understand the process of (trans)formation of Business Education and its relationship with the emergence of higher education courses in Accounting, Economics and Administration throughout of the 20th century. Therefore, we will show the origin and the most relevant events of Commercial Education in the following periods: a) Empire Brazil b) first period of the Vargas Era, c) Dictatorial Government of Getúlio Vargas, also known as Estado Novo and d) redemocratization of Brazil, also known as the Second Republic. As methodological aspects, this research is classified in relation to its nature as basic; qualitative approach. Regarding the objectives, it is descriptive and the technical procedure used was bibliographical and documentary research. In the results of this bibliographical review, we present the relevance of understanding the history of courses and school subjects, in particular, Commercial Education, in its historical processes of genesis, consolidation and insertion in the history of school institutions.
\end{abstract}

Keywords: Commercial education; Technical education; College education; Teaching; Accounting sciences; Economic sciences; Administration.

\section{Resumen}

La trajectoire historique de l'enseignement des sciences comptables, des sciences économiques et de l'administration au Brésil nous ramène aux débuts de l'enseignement commercial dans le pays, qui était le prédécesseur historique des trois cours mentionnés. Dans cette perspective, l'objet de cet article est de présenter l'origine et l'histoire de la Business Education, afin de mieux comprendre le processus de (trans)formation de la Business Education et sa relation avec l'émergence de formations supérieures en Comptabilité, Economie. et de l'administration tout au long du 
XXe siècle. Par conséquent, nous montrerons l'origine et les événements les plus pertinents de l'éducation commerciale dans les périodes suivantes: a) Empire Brésil b) première période de l'ère Vargas, c) Gouvernement dictatorial de Getúlio Vargas, également connu sous le nom de Estado Novo et d) redémocratisation du Brésil, également connue sous le nom de Deuxième République. En tant qu'aspects méthodologiques, cette recherche est classée par rapport à sa nature comme fondamentale ; approche qualitative. Concernant les objectifs, il est descriptif et le procédé technique utilisé a été la recherche bibliographique et documentaire. Dans les résultats de cette revue de littérature, nous présentons la pertinence de comprendre l'histoire des cours et des matières scolaires, en particulier, l'Enseignement Commercial, dans ses processus historiques de genèse, de consolidation et d'insertion dans l'histoire des institutions scolaires.

Palabras clave: Educación comercial; Educación técnica; Educación universitaria; Ensenãnza; Contabilidad; Ciencias económicas; Administración.

\section{Introdução}

O objetivo deste artigo é apresentar a origem e a história do Ensino Comercial no Brasil, para que possamos compreender melhor o processo de (trans)formação do Ensino Comercial e dos demais cursos relacionados surgidos durante o século XX. Esclarecemos que enquanto outros segmentos, temos os cursos de Ciências Contábeis, Ciências Econômicas e Administração, cursos que se consolidaram no Brasil desde meados do século XX.

Nesse contexto, esperamos contribuir com a história da educação brasileira, notadamente, da formação e constituição de cursos e currículos escolares na história da educação brasileira, em especial, do Ensino Comercial.

Mais especificamente, o fenômeno a ser estudado se refere à particularidade de perda de status do Ensino Comercial frente aos novos desafios que passaram a ser apresentados no contexto brasileiro no século XX. e na transformação de curso para disciplina, em sua maioria.

Outra constatação importante, neste contexto, se refere à busca nos grandes buscadores da internet pelas palavras chaves: Curso de Comércio e Ensino Comercial, que nos mostra os pouquíssimos resultados comparados às três outras formações relacionadas em Nível Superior: Ciências Contábeis, Ciências Econômicas e Administração.

\section{Metodologia}

Este artigo apresenta parte dos resultados alcançados na tese intitulada: Gênese, implantação e consolidação da Faceu - Faculdade de Ciências Econômicas de Uberlândia-MG (1962-1978) defendida no final de 2020 na UNIUBE, Universidade de Uberaba.

Em relação à sua natureza este artigo se classifica como pesquisa básica e qualitativa. É de natureza descritiva em relação aos seus objetivos. Os procedimentos técnicos utilizados foram à pesquisa bibliográfica realizada em fontes secundárias representada por livros e artigos científicos, bem como documental (Ludke \& André, 2013), pois foram pesquisadas as legislações relevantes para os temas pesquisados.

\section{Ensino Comercial}

O Ensino Comercial no Brasil foi durante décadas a formação disponível para as atuais áreas de Ciências Contábeis, Ciências Econômicas e Administração. Nesta perspectiva, Canabrava, ressaltou que "se analisarmos o envolver do Ensino da Ciência Econômica, verificamos, que em suas mais remotas origens, identifica-se com aulas de comércio no início do século passado, e do interesse, sobretudo, das camadas médias da população" (CANABRAVA, 1985, p. 26). 
Esta modalidade de ensino teve início no Brasil com a chegada da família real no País, em 1808, período no qual foi iniciada a cadeira de Economia Política ${ }^{1}$ no Rio de Janeiro. Em 1809, começaram as Aulas de Comércio, as quais já existiam em Portugal e foram frutos das reformas instituídas pelo Marquês de Pombal. ${ }^{2}$

No decreto de 09 de janeiro de 1825 foi elencada a disciplina obrigatória de Economia Política na estrutura curricular de um curso jurídico criado no Rio de Janeiro. Em 1846 com o decreto 456, responsável por regulamentar as aulas de Comércio, a disciplina de Economia Política também é inclusa no Ensino Comercial, juntamente com a disciplina de guardalivros ${ }^{3}$. Assim, dentre os três cursos relacionados à área de Negócios, o curso de Economia e Contábeis possuem maior destaque, em seus primórdios, em comparação com o curso de Administração. E, nesse contexto, a demanda por profissionais capacitados para o comércio permitiu o desenvolvimento de outras conquistas, tais como a criação do Código Comercial Brasileiro com a Lei ${ }^{\circ} 556$ de 1850.

Outra reforma nas Aulas de Comércio, ocorreu por meio do Decreto 769 de 1854, que fixou em até vinte mil réis, a "contribuição" dos estudantes, bem como, determinou que o Imperador do Brasil, não poderia exceder nas despesas a quantia de cinco contos de réis, que era o custo do ensino.

Em 1856, a partir do decreto $\mathrm{n}^{\circ} 1763$ foi criado o Instituto Comercial do Rio de Janeiro, que substituiu as iniciativas anteriores e foi responsável por sistematizar as técnicas comerciais no Brasil. Nesse decreto, foram incluídas duas disciplinas relevantes ao desenvolvimento da área de negócios: Direito Mercantil e Economia Política com aplicação ao comércio e indústria, o que permitiu uma maior aproximação da área econômica com a área do Direito, enquanto disciplina que também poderia ser ministrada para os futuros advogados.

Para o curso de Ciências Contábeis merecem destaque, em especial, os seguintes acontecimentos:

a) Promulgação da Lei $n^{\circ} 1083$, em 1860, que determinava a fixação de conteúdos sobre bancos de emissão, das companhias e sociedades, considerada por vários estudiosos, (Silva, 1980, Franco, 1988, Schmidt, 2000) como a primeira Lei das Sociedades Anônimas no Brasil;

b) fundação da Associação de Guarda-Livros, em 1869;

c) reconhecimento oficial do Estatuto da Associação de Guarda-livros por meio do Decreto Imperial 4475 de 1870.

E, assim a profissão de contador, se tornou uma das primeiras profissões liberais regulamentadas no Brasil e primeira do rol das profissões relacionadas às ciências empresariais. Além disso, no decreto de reconhecimento profissional foram estabelecidos que, para o ensino da profissão, deveriam ser elencadas as disciplinas de Direito Mercantil e Economia Política, por serem estas de grande utilidade para a profissão (Art. $1^{\circ}, \S 3$ ).

E, assim, enquanto o Curso de Ciências Contábeis se desenvolvia em termos profissionais, o curso de economia, consolidava-se na área do ensino, pois em 1873, com a constituição formal dos cursos de Engenharia, disciplinas na área de economia também se tornaram obrigatórias, favorecendo, assim o advento do Ensino de Economia, posteriormente. Dessa forma, os preceitos do ensino de economia se mostravam relevantes no ensino comercial, jurídico, contábil e da engenharia.

No decorrer do século XIX, tivemos também outros decretos para o Ensino Comercial, os quais em suma, foram responsáveis por reformas curriculares e na carga horária. No entanto, poucos estudantes demandavam estes cursos e uma

\footnotetext{
${ }^{1}$ As origens do Ensino Superior em Ciências Econômicas no Brasil são atribuídas, em especial, a Visconde de Cairu (José da Silva Lisboa - 1756-1835) a partir da publicação da obra: Princípios de Economia Política, em 1804. (Schmidt, 2000).

${ }^{2}$ Primeiro ministro de Portugal de 1750-1777. (na época do rei Dom José I) - Na verdade o cargo do Marquês de Pombal se chamava: Secretário de Estado (que na prática corresponde ao que se chama habitualmente de Primeiro-Ministro).

${ }^{3}$ Guarda-livros era a denominação atribuída aos técnicos em contabilidade, na época.
} 
explicação para isto seria o desprestígio atribuído aos cursos dessa natureza, pois a preferência social era a formação de engenheiros, advogados, militares e médicos. (Aranha, 1996).

Para uma melhor compreensão desse contexto, enquanto o Curso Superior de Direito contou com 826 estudantes matriculados em 1864, o Instituto Comercial do Rio de Janeiro, em suas Aulas de Comércio tinha 38 estudantes em 1875. O número reduzido de estudantes nessas aulas, também ocorreu em outras datas (Canabrava, 1985). Isso justifica "o fato de até 1931 não haver ainda um curso superior específico que formasse pessoas nas áreas econômica, administrativa ou contábil, já que esses não eram cursos direcionados aos filhos e filhas das elites”. (Barros, 2013, p. 86).

Outro marco relevante em relação ao Ensino Comercial foi à institucionalização da Academia de Comércio do Rio de Janeiro a partir do Decreto 1.339, de 09 de janeiro de 1905 (Brasil, 1905). Ela foi, então, destinada à Educação Superior do comércio, como instituição de utilidade pública, passando assim a reconhecer os diplomas por esta instituição conferidos. Esse mesmo decreto também estabeleceu as condições e normas para ingresso, progressão e conclusão dos cursos e atribuiu o reconhecimento estatal à Escola Prática de Comércio de São Paulo, atual Fundação Escola de Comércio Álvares Penteado, que havia sido fundada em 1902 (Brasil, 1905).

Em relação à expansão do Ensino Comercial pelo território brasileiro, ressaltamos que foi fundada em 1894 a Academia de Comércio na Cidade de Juiz de Fora (Yazbeck, 1999). "Na década de 1910 foram criadas escolas comerciais em outros Estados, além de duas existentes no Paraná e uma em São Paulo. Até 1912 foram criadas escolas no Amazonas, Maranhão e Pernambuco". (Souza, 2006, p. 380).

Em termos de Ensino Comercial na universidade, temos a Universidade do Paraná, criada em 1912 e extinta em 1915, que oferecia os seguintes cursos: Direito, Engenharia, Farmácia, Odontologia e Comércio. Entretanto, ela somente foi reconhecida como instituição de Ensino Superior em 1946, pois o governo federal, amparado no Decreto-lei ${ }^{\circ}{ }^{\circ} 11.530$, de março de 1913, justificou que a cidade tinha menos de 100.000 habitantes, o que não significou a ausência de seu funcionamento, mesmo não sendo oficializada.

Convém ressaltar que o Brasil foi um dos últimos países do continente americano a ter uma Universidade, mas cursos superiores existiam desde a época em que a família real portuguesa esteve no Brasil. O reconhecimento da primeira Universidade brasileira de Ensino Superior ocorreu em 1920, por meio do decreto 14.343. Uma das explicações para esse atraso é atribuída aos nossos colonizadores que "eram favoráveis a cursos técnicos profissionalizantes, considerando a universidade anacrônica para o Novo Mundo" (Oliven, 1992, p. 89). No entanto, convém ressaltar que outros autores enfatizaram que os colonizadores não investiram em Educação Profissionalizante (Caires, Oliveira, 2016). Contudo, sabemos que Portugal durante todo o período colonial procurou valorizar a Universidade de Coimbra e assim pode ter ocorrido desmotivação ou mesmo proibição de abertura de universidade no Brasil.

O ensino superior no Brasil só veio a adquirir cunho universitário nos anos 30, em contraste com alguns países da América espanhola que tiveram suas primeiras universidades ainda no período colonial, como o México e Peru1, ou no pós independência, como o Chile. Por mais de um século, de 1808 - quando foram criadas as primeiras escolas superiores - até 1934, o modelo de ensino superior foi o da formação para profissões liberais tradicionais, como direito e medicina, ou para as engenharias. (Sampaio, 1991, p. 03).

Dentre os três cursos analisados neste artigo, ressaltamos que em 1919, sem reconhecimento formal, foi criada a primeira faculdade de Economia: Faculdade de Ciências Políticas e Econômicas do Rio de Janeiro. Em 1926, o Decreto 17.329 formaliza os cursos profissionalizantes ou de Ensino Técnico Comercial e também reconhece o título de graduado em Ciências Econômicas e Comerciais. No entanto, não era atribuído o título de bacharel, pois este título era reservado somente aos formados em Medicina, Engenharia e Direito. Assim, mais uma vez, constatamos o caráter discriminatório referente ao status dos cursos, em especial, da área de Negócios. 
Esse mesmo decreto aprovou a oferta de cursos nas seguintes condições:

- Curso de formação geral: com duração de quatro anos e idade mínima de 13 anos para acesso e concessão do diploma de contador;

- Curso de nível superior: com duração de três anos, idade mínima de 17 anos e atribuição do título de graduado em Ciências Econômicas e Comerciais.

Nesse contexto, ressaltamos outra dimensão norteadora sobre o antecedente histórico, desta vez, do curso de contabilidade, a partir da seguinte determinação "Approva, o regulamento para os estabelecimentos de ensino technico commercial reconhecidos officialmente pelo Governo Federal". Em seu artigo 11, era determinado "conceder diplomas sómente aos alumnos que concluirem os cursos regulares, sendo o de contador após o curso geral”. (Brasil, 1926). (sic)

Dessa forma, era exigido o título de contador (Técnico em Contabilidade - atual Ensino Médio) para o ingresso no Curso Superior de Ciências Econômicas e Comerciais, mantendo dessa forma dependência e ligação entre as formações.

De modo geral, o Ensino Comercial no Brasil mudou vagarosamente ao longo do século XIX e XX, assim como outros cursos também. Mas, veremos a seguir que a estruturação do Ensino Superior no País por meio de legislações na área educacional contribuiu para o desenvolvimento do Ensino Comercial e implantação dos três cursos relacionados às ciências empresariais no século XX.

\section{Reformas, Educação Superior e Universidades no Brasil}

Dessa forma, o período que antecede o Governo Provisório de Getúlio Vargas (1930-1934) abrigou a existência de dois movimentos educacionais. Um destes é conservador, representado por grupos confessionais, que consideravam a interferência do Estado na educação uma ameaça ao monopólio exercido pela Igreja Católica. O outro é composto pelos renovadores, os quais conquistaram espaço no debate nacional, a partir da fundação da Associação Brasileira de Educação (ABE), em 1924, no Rio de Janeiro. Os idealizadores desse projeto tinham como objetivo a discussão de políticas educacionais, defesa da Escola pública, laica e gratuita e traziam sugestões pautadas no diálogo com a sociedade civil.

A adesão a $\mathrm{ABE}$ reunia, além de professores, diferentes membros da sociedade, interessados em mudanças nos rumos da educação nacional. Ainda "representava, antes, a tomada de consciência e o compromisso assumido por um grupo no engajamento por uma luta que iria perdurar por alguns decênios" (Romanelli, 2007, p. 129). Além disso, a associação era "resultado da influência das ideias então vigentes nos Estados Unidos e na Europa e consubstanciadas, às vezes vistas de maneira impropriamente reunidas, sob o nome de "Movimento de Escolas Novas" (Romanelli, 2007, p. 129) ou escolanovismo.

A "Escola Nova" surgiu no século XIX, trazendo à tona críticas à escola tradicional e à defesa pelo direito de todos à educação. Nesse contexto, defendiam-se a igualdade entre os homens, a aprendizagem ativa, o "aprender fazendo", a escola com centralidade nos estudantes, o ensino laico, com destaque para as dimensões psicológicas e sociológicas na educação, dentre outros princípios.

Os embates entre esses dois movimentos foram intensos, até que em 1930 os renovadores assumiram o poder com Getúlio Vargas no governo provisório. Para tanto e atendendo aos preceitos de modernização do País, logo, em novembro de 1930, foi criado o Ministério da Educação e Saúde Pública (Romanelli, 2007). Nesse contexto, era iniciado o primeiro período do governo de Getúlio Vargas.

Nesse contexto, Francisco Campos (1891-1968), considerado um reformador na educação do Estado de Minas Gerais, assumiu o posto de ministro do recém-criado Ministério da Educação e Saúde Pública e sistematizou algumas medidas, denominadas como Reforma Francisco Campos. Suas ações contemplavam a efetivação de vários decretos, por meio dos quais as universidades começaram a ganhar força. 
Enquanto uma das principais características desta reforma, convém citar que pela primeira vez na história da educação no Brasil a organização do ensino foi colocada em nível nacional, e não estadual, como acontecia em períodos anteriores (Aranha, 1996). Nesse contexto, ela surgia como uma prioridade na agenda do governo federal. Para o propósito deste artigo, convém citar as quatro medidas da Reforma Francisco Campos, mencionadas na Figura 1, seguinte:

Figura 1: Reformas de Francisco Campos relacionadas ao Ensino Comercial e Superior.

Criação do Conselho Nacional de Educação (Decreto $\mathbf{n}^{\circ} 19.850$, de 11 de abril de 1931)

Organização do Ensino Superior no Brasil e adoção do regime universitário - Estatuto das Universidades Brasileiras (Decreto $n^{\circ} 19.851$, de 11 de abril de 1931)

Organização da Universidade do Rio de Janeiro (Decreto $\mathrm{n}^{\circ} 19.852$, de 11 de abril de 1931)

Organização do ensino comercial e regulamentaçăo da profissão de contador (Decreto $\mathrm{n}^{\circ} 20.158$, de 30 de junho de 1931)

Fonte: Autores.

No que concerne ao Conselho Nacional de Educação (Primeiro item da figura 1), sua finalidade foi assim descrita: “destina-se a collaborar com o Ministro nos altos propositos de elevar o nivel da cultura brasileira e de fundamentar, no valor intelectual do indivíduo e na educação profissional apurada, a grandeza da Nação.” (BRASIL, 1931a, ART. 2º). (sic) Ainda, a composição desse conselho obedeceria aos seguintes critérios:

I - Um representante de cada universidade federal ou equiparada.

II - Um representante de cada um dos institutos federais de ensino do direito, da medicina e de engenharia, não encorporados a universidades.

III - Um representante do ensino superior estadual equiparado e um do particular tambem equiparado.

IV - Um representante do ensino secundário federal; um do ensino secundário estadual equiparado e um do particular tambem equiparado.

V - Três membros escolhidos livremente entre personalidades de alto saber e reconhecida capacidade em assumptos de educação e de ensino. (Brasil, 1931a, ART. $3^{\circ}, \S 1^{\circ}$ ). (sic)

Podemos partir do pressuposto de que esse conselho era representado por diferentes membros da sociedade. Contudo, tal representação era vulnerável diante da dependência tanto administrativa quanto burocrática das universidades em relação ao Ministério da Educação, de cunho altamente centralizador foi estabelecido que "nas universidades officiaes, federaes ou estaduaes, quaesquer modificações que interessem fundamentalmente á organizacção administrativa ou didactica dos institutos universitarios, só poderão ser effectivadas mediante sancção dos respectivos governos, ouvido o Conselho Nacional de Educação (BRASIL, 1931b, Art. 9º Parágrafo único). (sic)

Essa citação nos permitiu adentrar em nosso segundo item de análise mostrado na figura 1 o Estatuto das Universidades Brasileiras (Brasil, 1931b). Cabe ressaltar que este era responsável por estabelecer que o Ensino Superior, preferencialmente, deveria ser oferecido em universidades.

Quanto à finalidade dessa modalidade de ensino, era previsto que "As universidades brasileiras desenvolverão acção conjuncta em benefício da alta cultura nacional, e se esforçarão para ampliar cada vez mais as suas relações e o seu 
intercambio com as universidades estrangeiras”. (Brasil, 1931b, ART. $4^{\circ}$ ). Com o passar do tempo, essa finalidade passou a ser assumida de forma cada vez mais vigorosa e ampliada, como será visto na revisão do governo ditatorial de Getúlio Vargas.

Em termos institucionais e administrativos, foram definidos os cargos de reitor, conselheiro universitário e diretor, em ordem decrescente de hierarquia. Havia também a existência de uma assembleia universitária.

Foi ainda estabelecida à exigência de "congregar em uma unidade universitária pelo menos três dos seguintes cursos do Ensino Superior: Faculdade de Direito, Faculdade de Medicina, Escola de Enfermagem e Faculdade de Educação, Ciências e Letras" (BRASIL, 1931b, Art. 5 I), não sendo, assim, consideradas como fundamental nenhuma das formações relacionadas às ciências empresariais. Ademais, foi feita referência não somente ao ensino, mas também à pesquisa e à extensão.

Em relação ao Decreto 19.852 de 11 de abril de 1931 (1931c), mostrado no terceiro item da figura 1, desta mesma reforma, foi estipulada a organização e consequentemente ampliação da Universidade do Rio Janeiro, a primeira universidade ininterrupta ${ }^{4}$ fundada no Brasil. A partir de 1937 passou a ser denominada de Universidade do Brasil.

Enquanto medida da Reforma Francisco Campos (Brasil, 1931c), a Universidade do Rio de Janeiro passaria a oferecer os seguintes cursos:

- $\quad$ Faculdade de Direito;

- $\quad$ Faculdade de Medicina;

- Escola Politécnica;

- $\quad$ Escola de Minas;

- $\quad$ Faculdade de Educação, Ciências e Letras;

- Faculdade de Farmácia;

- $\quad$ Faculdade de Odontologia;

- $\quad$ Escola Nacional de Belas Artes;

- Instituto Nacional de Música.

Podemos observar que, mais uma vez nos decretos de Francisco Campos, não foi implantado nenhum curso diretamente relacionado ao ensino das ciências empresariais. A graduação que manteve maior proximidade a essa temática foi a de Direito, que compreendia em sua grade curricular as disciplinas de Direito Comercial, Direito Administrativo, Economia Política e Finanças.

A ausência mencionada foi assim justificada:

$\S 2^{\circ}$ Oportunamente serão organizadas e incorporadas pelo Governo à mesma Universidade a Escola de Higiene e Saude Pública e a Faculdade de Ciências Políticas e Econômicas.

$\S 3^{\circ}$ Os institutos, de que trata o parágrafo anterior, destinados a preparar técnicos que se propõem ao exercício de funções sanitárias ou ao desempenho de atividades administrativas, públicas e privadas, obedecerão a regulamentos a serem expedidos pelo ministro da Educação e Saude Pública. (BRASIL, 1931c, ART. $1^{\circ}$ ). (sic).

Analisando, especificamente, a Reforma Francisco Campos (último item da figura 1), em relação à organização do Ensino Comercial (Decreto ${ }^{\circ} 20.158$, de 30 de junho de 1931) é possível perceber o caráter formativo para o trabalho, tanto em termos de ensino básico ou Ensino Fundamental, na atualidade, por um lado, que oferecia o curso elementar de Auxiliar de Comércio e contemplava as seguintes disciplinas: caligrafia, datilografia, português, inglês, aritmética, contabilidade (noções

\footnotetext{
${ }^{4}$ Existiam algumas faculdades isoladas pelo país, cursos de licenciatura e de bacharelado. Três destas, a Faculdade de Medicina, a Escola Politécnica e a Faculdade de Direito, localizadas no Rio de Janeiro, foram integradas e originaram a primeira universidade no Brasil, a partir do Decreto ${ }^{\circ}$ 14.343, de 7 de setembro de 1920 (Brasil, 1920). No entanto, ressaltamos a existência da primeira Escola Universitária Livre de Manaus, fundada em 1909. Em seguida, surgiu a Universidade Federal do Paraná, em 1912, conforme ressaltado anteriormente.
} 
preliminares) e contabilidade mercantil. Desta forma, percebemos o caráter tecnicista ao contemplar mais as demandas de mercado do que a formação integral dos estudantes, pois não eram oferecidas disciplinas, tais como: história, geografia, história ou economia.

Por outro lado, temos a formação técnica oferecida no Ensino Secundário, que oferecia os seguintes cursos: secretário, guarda-livros, administrador-vendedor, atuário e de perito-contador. Assim, "os cursos básicos e médios preparavam os estudantes para o mercado de trabalho; de outro, um ensino propedêutico destinado a grupos mais abastados da sociedade visava permitir o acesso aos bacharelados". (Barros, 2013, p. 86).

Nesta perspectiva, o terceiro artigo do Decreto 20.158, de 30 de junho de 1931, especificou o Exame de Admissão para os cursos propedêuticos e de auxiliar do comércio, os quais se dariam pelo exame em provas escritas e orais das disciplinas de português, francês, aritmética e geografia. Entretanto, o sistema primário não oferecia o curso de francês e, dessa forma, somente a elite poderia pagar pelos custos extraescolares de seus filhos, impedindo que as classes menos favorecidas tivessem acesso aos cursos propedêuticos que visavam o acesso à graduação. E, assim, constatamos a separação de duas escolas diferentes, uma para cada classe social, ou seja, escola para rico e para pobre, caracterizando, desta forma, o chamado Dualismo Escolar.

Tal prática tendenciosa é confirmada no parágrafo primeiro deste mesmo artigo no seguinte teor: "Será considerado aprovado o candidato que obtiver, além de nota igual ou superior a três em cada disciplina, como média das notas de prova escrita e prova oral, média igual ou superior a cinco no conjunto das disciplinas" (BRASIL, 1931c, Art. $3^{\circ}$, § $1^{\circ}$ ). Isso nos permite verificar que a obtenção de êxito em todas as outras disciplinas não bastariam, pois a prova de francês não poderia ser zerada, devido à exigência de a nota mínima ser três.

Além disto, podemos analisar que a aprovação para o curso de Auxiliar de Comércio também era dependente da nota na prova de francês. Assim, encontramos mais um processo de exclusão, em que apesar de terem previsto a oferta do curso, não teríamos estudantes aprovados e assim a oferta se tornaria inviável.

Ademais, outro critério de exclusão está presente no parágrafo segundo: "Fica dispensado do exame de admissão o candidato que exibir certificado de aprovação na $1^{\text {a }}$ série do Colégio Pedro II, dos estabelecimentos de ensino secundário a ele equiparados [...] fiscalizados ou mantidos pela União ou pelos Estados”. (Brasil, 1931c, Art. $3^{\circ}, \S 2^{\circ}$ ). No entanto, nem todos conseguiam acesso a esses colégios e eles nem mesmo existiam em todas as cidades e para entrar neles havia também processos seletivos 5 .

Outra relevante contribuição da Reforma Francisco Campos (Brasil, 1931d), diante da necessidade de inserção no processo foi à criação da graduação de Administração e Finanças e organização do seu currículo. Enquanto particularidade desse decreto, os formados no curso superior de Administração e Finanças recebiam a designação de bacharéis em Ciências Econômicas, o que mostra que faltavam evidências em relação às diferenças entre ambos, bem como, os limites de cada uma dessas áreas.

Além disto, os bacharéis em Ciências Econômicas tinham preferências por ocupar cargos públicos e por assumir funções de docentes nos estabelecimentos de Ensino Comercial. Já os profissionais de prestígio em suas áreas, como por exemplo, em Direito, poderiam ser convidados a lecionar, sem, no entanto, possuir a formação de bacharelado em Ciências Econômicas ${ }^{6}$.

\footnotetext{
${ }^{5}$ A partir de 1931, a Organização Escolar Brasileira ficou dividida em Ensino Primário e Ensino Secundário (secundário dividido em Ginasial e Colegial). Na passagem do Primário para o Secundário havia o Exame de Admissão.

${ }^{6} \mathrm{Na}$ década de 1970, começou a serem exigidos os cursos de bacharelado e exercício profissional, poisrecentemente, os professores universitários começaram a se conscientizar de que a docência, como a pesquisa e o exercício de qualquer profissão, exige capacitação própria e específica. O exercício docente no ensino superior exige competências específicas, que não se restringem a ter um diploma de bacharel, ou mesmo de mestre ou doutor, ou ainda, apenas o exercício de uma profissão. Exige tudo isso, além de outras competências próprias. (Masetto, 1998, p. 11).
} 
Em termos de gestão hierárquica e conforme os preceitos estabelecidos na organização do Ensino Superior (Decreto $n^{\circ}$ 20.158, de 30 de junho de 1931), em especial, essa reforma também implementou diretrizes para o Ensino Comercial. Assim, foi estabelecida a Superintendência do Ensino Comercial, antes denominada como Superintendência de Fiscalização dos Estabelecimentos do Ensino Comercial, que tinha como incumbência a responsabilidade de fiscalizar e emitir reconhecimentos às fundações e sociedades particulares, nos âmbitos estadual e municipal (Brasil, 1931d, Art. 34).

Enquanto crítica fica evidente a centralização das decisões com rígida fiscalização e consequente controle da estrutura de ensino, o que tornava a estrutura de ensino inflexível. Em especial, a partir da menção "Os programas serão aprovados todos os anos pelo superintendente que, em caso de protesto por parte da escola, os remeterá ao Conselho Consultivo do Ensino Comercial” (Brasil, 1931d, ART. 23, § ÚNICO).

O mesmo pode ser constatado no seguinte trecho do Artigo 25: "para tudo o que estiver fora dos preceitos e das instruções expedidas pela Superintendência do Ensino Comercial, podendo propôr a suspensão das regalias das escolas se estas não atenderem às suas exigências". (Brasil, 1931d, ART. 25). (sic)

O artigo 32 (Brasil, 1931d) foi responsável pela criação do Conselho Consultivo do Ensino Comercial. Ele também esclarecia que o cargo de presidente efetivo seria destinado ao ministro da educação, e seu vice seria o superintendente do Ensino Comercial. O decreto também exigia que as instituições de Ensino Comercial deveriam estar equiparadas ao padrão federal, em atendimento ao disposto no artigo 35. "Todos os estabelecimentos de ensino comercial, de ciencias economicas e de administração, pertencentes a fundações, sociedades particulares, estados e municipios, para que gosem dos favores legais devem ser equiparados ao padrão federal, requerendo fiscalização e reconhecimento pela Superintendencia do Ensino Comercial. (Brasil, 1931d, Art. 35). (sic).

No que tange à formação em Economia, em 1935 surgiu o curso de Estudos Econômicos, na recém-criada Universidade de Porto Alegre que foi criada em novembro de 1934, a partir da integração de Escolas pré-existentes que ministravam os seguintes cursos: Engenharia; Astronomia; Eletrotécnica e Química Industrial; Medicina; Odontologia e Farmácia; Agronomia e Veterinária; Filosofia; Ciências e Letras, Instituto de Belas Artes e, a Faculdade de Direito, que contava com uma Escola de Comércio.

Prosseguindo em nossas discussões, mais especificamente na análise da última medida da Reforma Francisco Campos (figura 1), nos deteremos na regulamentação da profissão de contador, conforme o Decreto n 20.158 , de 30 de junho de 1931.

\section{Administração, Economia e Ciências Contábeis: a verticalização do Ensino Comercial}

Diferentes estudos (Fernandes, 2013, Quevedo, 2016, Rôças, Bomfim, 2017, Bomfim, Rôças, 2018) avaliaram a prática da verticalização do ensino, em especial, nos Institutos Federais de Educação, Ciência e Tecnologia. Nestas instituições de ensino é ofertada desde a Educação Básica à Profissional e Educação Superior em um mesmo espaço e compartilhando corpo docente e instalações de forma integrada. Esses estudos destacam que a verticalização pode ocorrer nas instituições quando oferecem diversos cursos na mesma área, por exemplo: Técnico em Administração e Bacharelado em Administração.

A verticalização também ocorre quando são criados cursos superiores que dão continuidade a formação técnica, como no caso aqui estudado, entre Técnico em Comércio e superior de Administração, Contabilidade e Economia. Outra possibilidade de verticalização ocorre no percurso formativo dos estudantes quando estes procuraram estudar em cursos da mesma área, ainda que em instituições diferentes, por exemplo: Técnico em Edificações e Engenharia Civil.

Nesta perspectiva, a Reforma Francisco Campos referendou que o curso técnico Comercial, o "Ensino Technico Commercial”, avanço já conquistado desde 1926, teria direito a prosseguir os estudos nos cursos superiores de Economia e Contabilidade, o que na época representava avanço importante conforme aponta Canabrava (Canabrava, 1985). 
No entanto, para nos situarmos na atual conjuntura, ressaltamos que a aprovação das leis, primeiramente de Flexibilização parcial (Brasil, 1950), Equivalência parcial (Brasil, 1953) e posteriormente de equivalência plena (BRASIL, 1961), favoreceram o processo progressivo de revogação das restrições de mobilidade entre cursos não equivalentes e consequentemente beneficiou a migração de estudantes entre os diferentes campos das Ciências Empresariais, devido à falta de impedimentos, ou seja, da formação anterior em Contabilidade para a matrícula, como por exemplo, no curso de Ciências Econômicas ou Administração. Para uma melhor compreensão desse contexto, expomos um esboço, em suma, da trajetória das Leis de Flexibilização e Equivalência conforme o Quadro 1, seguinte:

Quadro 1: Leis da Flexibilização e Equivalência.

\begin{tabular}{|l|l|l|}
\hline $\begin{array}{l}\text { Lei } \mathrm{n}^{\circ} 1.076 \mathrm{de} \\
31 / 03 / 1950\end{array}$ & $\begin{array}{l}\text { Assegura aos estudantes que concluírem curso de primeiro } \\
\text { ciclo do ensino comercial, industrial ou agrícola, o direito à } \\
\text { matrícula nos cursos clássico e científico e dá outras } \\
\text { providências. }\end{array}$ & $\begin{array}{l}\text { Flexibilização parcial: "Exame das } \\
\text { disciplinas não estudadas" }\end{array}$ \\
\hline $\begin{array}{l}\text { Lei } \mathrm{n}^{\circ} 1.821 \text { de } \\
12 / 03 / 1953\end{array}$ & $\begin{array}{l}\text { Dispõe sôbre o regime de equivalência entre diversos } \\
\text { cursos de grau médio para efeito de matrícula no ciclo } \\
\text { colegial e nos cursos superiores. (sic) }\end{array}$ & $\begin{array}{l}\text { Equivalência Parcial: } \\
\text { "Exames de Adaptação" }\end{array}$ \\
\hline $\begin{array}{l}\text { Lei } \mathrm{n}^{\circ} 4.024 \text { de } \\
20 \text { de dezembro } \\
\text { de } 1961\end{array}$ & LDB de 1961 & $\begin{array}{l}\text { Equivalência Plena: "a articulação sem } \\
\text { restriçóes entre os ensinos secundário e } \\
\text { profissional" }\end{array}$ \\
\hline
\end{tabular}

Fonte: Curi (2018).

Sobre o processo de definição das Leis de Equivalência e suas contribuições para o desenvolvimento social do Brasil, a partir da década de 1930, Canabrava (1985, p. 24), destacou "a pressão que concomitantemente as camadas médias exerceram no sentido da equivalência entre os diversos cursos do segundo grau, ou seja, a circulação ascendente entre vários graus de ensino, rumo ao superior."

Mas, antes das mudanças acima, muito se discutiu e algumas legislações foram alterando o contexto da época. Como exemplo, podemos citar, em especial, o decreto 20.158 (Brasil, 1931d) que estabeleceu que aos formados do curso técnico, seria atribuído o título de perito-contador, o que foi alterado somente em 1939 por meio do decreto-lei 1.535 de 23 de agosto de 1939 para o título de contador.

E, nesse período de efervescentes mudanças iniciadas com o golpe e a tomada de poder pelo presidente Getúlio Vargas, em 1930, as novas elites política e econômica brasileiras aspiravam mudanças no País e nesse contexto, Vargas buscou implementar algumas medidas visando agradar a classe média. Para tanto, foi fundado, em 1931, o Instituto de Organização Racional do Trabalho (Idort). Ele tinha como objetivo disseminar os conhecimentos oriundos das abordagens administrativas, espelhadas no modelo estadunidense.

Nesse teor, o Idort inaugurou no Brasil o início da história da aplicação das teorias da Administração e foi declarado como utilidade pública com sede em São Paulo, por meio do Decreto no 1.155, de 19 de outubro de 1936 (Brasil, 1936) e assim foi iniciado o processo de aplicação e consequente dependência do Brasil em relação a teorias administrativas estrangeiras.

E, por nos referirmos aos acontecimentos e reformas educacionais no País, desse período, convém acrescentarmos, nesta parte do texto, mais um movimento ocorrido, na Era Vargas: o "Manifesto dos Pioneiros da Educação Nacional", publicado em 1932. Este é resultado de um documento redigido por 26 líderes do Movimento Renovador, fruto de acepções diversas dos reformadores, bem como, da adoção de discursos e instabilidades na aplicação dos ideários da Escola Nova.

Nesse manifesto, foi apresentada a necessidade de os professores terem formação universitária, do ensino laico, obrigatório, gratuito e público, sem privilégios destinados a uma minoria. Era mais um movimento a ser acrescentado na pauta de discussões entre as correntes conservadoras e reformadoras em que 
a inconsistência, porém, acompanhou a execução dessas reformas e movimentos. E isso por causa de seu principal defeito: eram reformas regionais, parciais, portanto. Não faziam elas parte de uma política nacional de educação, estando, então, sujeitas a todas as consequências advindas de reformas limitadas a segmentos do território e da população e sujeitas às instabilidades do poder público local, e inseridas num contexto territorial, demográfico, econômico, político e cultural desigualmente desenvolvido. (Romanelli, 2007, p. 130).

Nesse período, em 1932, o País contava com duas universidades: no Rio de Janeiro e em Minas Gerais. Essa última foi fundada pelo Decreto $n^{\circ} 956$ (Brasil, 1927) a partir da integração de quatro faculdades: Direito, Medicina, Engenharia, Odontologia e Farmácia.

Vale ressaltar que a Universidade de São Paulo, terceira universidade a ser fundada no Brasil, foi instituída a partir do Decreto 6.284, de 25 de janeiro de 1934. Na obra: A Universidade da Comunhão Paulista, são descritos os embates ideológicos travados nessa instituição. Ela foi responsável por implantar a formação de elites e dirigentes do País, em vez de apresentar conquistas relacionadas aos objetivos educacionais renovadores, conforme Cardoso (1982).

Adentrando o território nacional, Anísio Teixeira foi o responsável pela criação da Universidade do Distrito Federal ${ }^{7}$ e implantação da Faculdade de Educação. Entretanto, por motivos financeiros e políticos, ela teve a curta duração de quatro anos, de 1935 a 1939.

Em termos políticos convém mencionar que Anísio Teixeira, um dos lideres dos educadores escolanovista, defendia a escola pública, laica e universal. Contudo, essas ideias contrariavam os setores conservadores vinculados à Igreja Católica, que foram responsáveis por gerar perseguições e embates pessoais.

Nesse contexto, dentre as mudanças impostas pela introdução da industrialização, foi abordado nesse Manifesto, à necessidade de diversificação do Ensino Superior. Partimos do pressuposto de que essa demanda contribuiu para a progressiva estruturação dos cursos da área das Ciências Empresariais.

A criação do Ministério da Educação e Saúde, em 1930, e a reforma Francisco Campos, em 1931, aliadas à reforma implementada posteriormente por Gustavo Capanema ${ }^{8}$, que será descrita adiante, foram responsáveis por instituir "os aportes oficiais necessários para a sistematização do ensino profissional comercial no país” (CINTRA, 2009, p. 242). Nesse contexto, além do Ensino Comercial, também tivemos o advento de legislações referentes à organização do Ensino Industrial. Assim, temos como objetivo retratar o período da história brasileira que teve início em 10 de novembro de 1937, no qual o governo Getúlio Vargas, apoiado pelos militares, implantou a ditadura do Estado Novo (1937 a 1945).

Nesse contexto, constatamos mais uma vez o caráter autoritário e centralizador de Getúlio Vargas responsável por mais um golpe em 1937 e centralização de todo o poder nacional, em todos os níveis. Neste contexto, ordenou o fechamento do legislativo, cancelamento do federalismo e das eleições para governadores e nomeação de interventores para cada Estado.

Um dos acontecimentos que merecem destaque nesse período foi à criação do DASP - Departamento Administrativo do Serviço Público, em 30 de julho de 1938, por meio do decreto-lei 579, que visava implementar reformas na administração pública brasileira e estava previsto na Constituição autoritária de 1937.

Logo, isso favoreceu a criação da Escola Superior em Administração e Negócios (Esan), na cidade de São Paulo, em 1941, sendo esta considerada a primeira escola a oferecer o ensino superior em Administração. Nela eram aceitos estudantes que não haviam concluído o Ensino Secundário. Ainda, seu modelo foi baseado no curso superior de Administração da Universidade de Harvard, nos Estados Unidos, com formação de dois anos, adicionada a um ano de especialização. No entanto, somente a partir de 1961 que ela foi reconhecida e autorizada a emitir diplomas oficiais, como poderá ser notado adiante.

\footnotetext{
${ }^{7}$ Essa universidade era mantida pelo governo do Distrito Federal, na época o Rio de Janeiro, e foi fechado pelo governo Getúlio Vargas por considerá-la inovadora e democrática demais para a época.

${ }^{8}$ Gustavo Capanema foi o 4o ministro da Educação do Brasil (1934-1945) e o 17o Presidente de Minas Gerais de 05 de setembro de 1933 a 15 de dezembro de 1933.
} 
Mas, no momento de sua fundação, a Esan não oferecia graduação em Administração, e sim os cursos superiores de Ciências Contábeis e Ciências Econômicas. Ambos foram reconhecidos em 1931 e 1935, respectivamente, momento no qual existiam apenas as formações profissionais, em nível de bacharelado de Medicina, Advocacia e Engenharia, apesar da demanda por outras instruções acadêmicas. Convém enfatizar que, apesar de essa instituição fazer referência aos conceitos de “administração e negócios", na realidade eram oferecidos somente como disciplinas nas primeiras graduações mencionadas.

Outro marco delimitador para a educação brasileira nesse período refere-se às contribuições do quarto ministro da Educação (1934-1945), Gustavo Capanema (1900-1985), advogado, político e professor mineiro9. Tais colaboraç̃es foram institucionalizadas a partir da Reforma Capanema, sob o nome de Leis Orgânicas do Ensino, que contemplou os decretos apresentados no Quadro 2, seguinte:

Quadro 2: Leis Orgânicas do Ensino.

\begin{tabular}{|c|c|c|}
\hline DECRETO $\mathbf{N}^{\circ}$ & DATA DE PUBLICAÇÃO & RESUMO DA EMENTA \\
\hline 4.073 & 30 de janeiro de 1942 & Organizou o Ensino Industrial. \\
\hline 4.048 & 22 de janeiro de 1942 & $\begin{array}{l}\text { Instituiu o Serviço Nacional de Aprendizagem Industrial } \\
\text { (Senai). }\end{array}$ \\
\hline 4.244 & 9 de abril de 1942 & $\begin{array}{l}\text { Organizou o Ensino Secundário em dois ciclos: o ginasial, } \\
\text { em quatro anos, e o colegial, em três anos. }\end{array}$ \\
\hline 6.141 & 28 de dezembro de 1943 & Reformou o Ensino Comercial. \\
\hline 8.529 & 2 de janeiro de 1946 & Organizou o Ensino Primário em nível nacional. \\
\hline 8.530 & 2 de janeiro de 1946 & Organizou o Ensino Normal. \\
\hline 8.621 e 8.622 & 10 de janeiro de 1946 & $\begin{array}{l}\text { Criaram o Serviço Nacional de Aprendizagem Comercial } \\
\text { (Senac). }\end{array}$ \\
\hline 9.613 & 20 de agosto de 1946 & Organizou o Ensino Agrícola. \\
\hline
\end{tabular}

Fonte: Autores, com base nas legislações do período.

Esclarecemos que dentre os decretos acima, teremos como foco apresentar e discutir os conteúdos do decreto que contribuíram para o advento dos cursos relacionados às Ciências Empresariais. Scwartzman (2005) ressaltou que o ministro Capanema se preocupou em oferecer o Ensino Secundário baseado nos ginásios ou liceus da Europa, que ofereciam formação humanística e científica como preparação para o ingresso nas universidades. Mas, na prática, a gestão Capanema também legislou sobre a Educação Profissional, embora preservasse as universidades para as elites da época (Romanelli, 2007).

Nesta perspectiva, além da ênfase atribuída ao Ensino Comercial, enquanto base para a origem dos cursos relacionados às ciências empresariais convém também reconhecer o mérito do Ensino Industrial enquanto propulsor do desenvolvimento das três áreas profissionais (Pedrosa, Santos, 2014).

O ensino das ciências empresariais focado no ambiente industrial passou a ser priorizado a partir da gestão presidencial de Juscelino Kubitschek (1956-1961), apesar de ter sido valorizado nos governos de Getúlio Vargas. Em suma, “A Revolução de 30, resultado de uma crise que vinha de longe destruindo o monopólio do poder pelas velhas oligarquias" (Romanelli, 2007, p. 60) permitiu o desenvolvimento das bases para a implantação do capitalismo industrial no Brasil, em uma conjuntura "profundamente marcada por uma herança cultural academicista e aristocrática". (Romanelli, 2007, p. 61).

\footnotetext{
${ }^{9}$ Convém salientar que, no final do mandato de Getúlio Vargas, mais especificamente nos decretos a partir de 30 de outubro de 1945, as legislações que estavam sendo tramitadas foram assinadas por Raul Leitão, por ter assumido o Ministério da Educação após Gustavo Capanema.
} 
E, foi com o Decreto 4.073 (Brasil, 1942) em 30 de janeiro de 1942 que o Ensino Industrial foi organizado com a seguinte menção "Esta lei estabelece as bases de organização e de regime do ensino industrial, que é o ramo de ensino, de grau secundário, destinado à preparação profissional dos trabalhadores da indústria e das atividades artesanais, e ainda dos trabalhadores dos transportes, das comunicações e da pesca”. (Brasil, 1942, Art. $1^{\circ}$ ).

Em suma, este decreto representava as novas exigências que a industrialização exigia, pois se tornou necessário o Estado prover mão de obra qualificada a um número crescente de pessoas que vinham do campo para os centros urbanos em busca de melhoria do padrão de vida e oportunidades de trabalho. Para tanto, o Ensino Industrial necessitava ser organizado, "pois a leitura e a escrita passam a ter preço, são sentidas como úteis e benéficas e a demanda do ensino normalmente se eleva, ao mesmo tempo, que maiores recursos advindo de maior produção, possibilitam maior e diferenciada oferta”. (Romanelli, 2007, p. 60). Enfatizamos, que mesmo após um século de independência, oitenta por cento da população brasileira era de analfabetos (Leite, 2005) e esclarecemos que apesar do presente artigo ter como o foco a Educação Superior, a capacitação profissional nas indústrias, seja em nível básico ou intermediário ofereceu fundamentos para uma melhor compreensão da Educação Superior nas áreas de Ciências Econômicas, Ciências Contábeis e Administração.

E, em se tratando do decreto 6.141 de 28 de dezembro de 1943 (Brasil, 1943) que teve como objetivo: reformar o Ensino Comercial, enquanto curso de nível de Ensino Secundário, foram estabelecidas as seguintes finalidades:

1. Formar profissionais aptos ao exercício de atividades específicas no comércio e bem assim de funções auxiliares de caráter administrativo nos negócios públicos e privados.

2. Dar a candidatos ao exercício das mais simples ou correntes atividades no comércio e na administração uma sumária preparação profissional.

3. Aperfeiçoar os conhecimentos e capacidades técnicas de profissionais diplomados na forma desta lei. (Brasil, 1943, Art. $1^{\circ}$ ).

Portanto, esses cursos eram voltados para a inserção no mercado de trabalho e não para a continuação dos estudos. No artigo $3^{\circ}$, do decreto 6.141, foram estabelecidas novas categorias e cursos para o Ensino Comercial, como ilustrado na Figura 2, seguinte:

Figura 2: Categorias de divisão do Ensino Comercial.
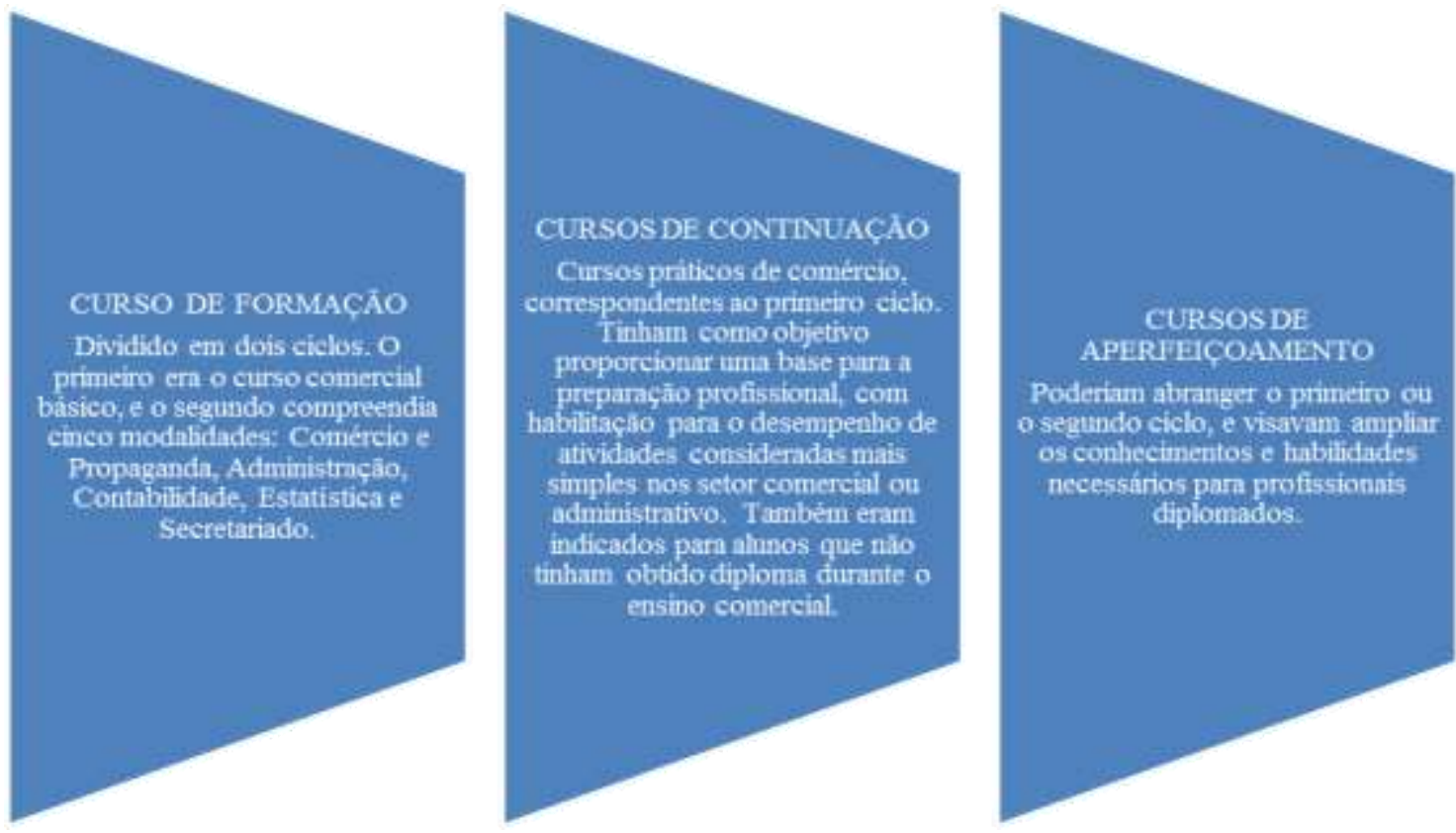

Fonte: Autores, com base na legislação (Brasil, 1943). 
Como pode ser observado, os cursos referentes à formação básica para o Ensino Comercial foram alterados, em comparação à Reforma de Francisco Campos, pois antes eram disponibilizadas as seguintes disciplinas: caligrafia, datilografia, português, inglês, aritmética, contabilidade (noções preliminares) e contabilidade mercantil. A partir dessa legislação (Brasil, 1943) passou a ser oferecido o Curso de Contabilidade e também de Administração.

Isso nos permite concluir que as modalidades relacionadas à profissionalização para o comércio estiveram mais presentes no cotidiano. Em relação à estrutura curricular, existiu a preocupação em oferecer tanto conteúdo de formação básica como de cultura técnica ou formação profissional. Com isso, partimos do pressuposto de que havia um contínuo empenho com a profissionalização no ensino, para atender o mercado de trabalho. Por força desse decreto (6141/1943), o curso de Administração e Finanças passou a ser jurisdição da diretoria do Ensino Superior do Ministério da Educação, promovendo melhor prestígio aos egressos, que antes era circunscrito à diretoria do Ensino (Brasil, 1943).

No art. 44 do Decreto 6.141 de 28 de dezembro de 1943, foi estabelecido que "o ensino comercial será ministrado pelos poderes públicos e é livre à iniciativa particular" (Brasil, 1943). Na mesma data deste decreto, também foi regulamentada a estrutura curricular dos cursos de formação do Ensino Comercial.

Convém ressaltar aqui que nesse período foram criadas as primeiras instituições do atual "Sistema S": Senai - Serviço Nacional de Aprendizagem Industrial (1942), Sesc - Serviço Social do Comércio (1946) e Senac - Serviço Nacional de Aprendizado Comercial (1946), enquanto entidades privadas com fins públicos, que visavam atender a formação de técnicos para atender a demanda por profissionais tanto no comércio, quanto na indústria. Ambas foram geradas após a criação da Confederação Nacional do Comércio de Bens, Serviços e Turismo, que é uma associação sindical patronal, fundada em 4 de setembro de 1945 e reconhecida pelo Decreto-Lei no 20.068 (Brasil, 1945).

Essa confederação tinha dois objetivos principais: congregação do empresariado na representação de seus direitos, em troca de contribuições compulsórias para a manutenção e o desenvolvimento das instituições citadas. Elas ficavam sob responsabilidade administrativa da confederação, o que perdura até os dias atuais, apesar das críticas recebidas, ou seja, dinheiro público para fins privados.

Convém lembrar que durante a Segunda Guerra Mundial, a imigração para as Américas e para o Brasil, em específico, ficou restrita e prejudicada o que propiciou e demandou o incremento de formação de mão de obra qualificada no próprio País. Nesse contexto, o Governo teve como objetivo de " engajar as indústrias na qualificação de seu pessoal, além de obrigá-las a colaborar com a sociedade na educação de seus membros. Esse fato decorreu da impossibilidade de o sistema de o ensino oferecer a educação profissional de que carecia a indústria e da impossibilidade de o Estado alocar recursos para equipá-lo adequadamente". (Romanelli, 2007, p. 155).

Esse engajamento estava resguardo pela Lei 4.073 em seu artigo 67 que tornou obrigatória a formação profissional na própria indústria dos empregados por seus empregadores e não podemos esquecer que tal capacitação favoreceu indiretamente a valorização das técnicas administrativas, contábeis e econômicas.

Nesse contexto, entre os avanços e retrocessos no tocante ao desenvolvimento dos cursos relacionados às Ciências Empresariais, enfatizamos que, em 1945, o Decreto-lei 7.988 definiu o surgimento do curso superior de Ciências Econômicas e de Ciências Contábeis e Atuariais, com duração de quatro anos e assim passou a conceder o título de bacharel em Ciências Econômicas e em Ciências Contábeis e Atuariais. Nesse contexto, os dois cursos se tornaram cursos de nível superior, equiparados a cursos como Medicina, Direito e Engenharia. Além disso, o Decreto-lei 7.988, enfatizou o seguinte: "Ficam extintos a partir do ano escolar de 1946 o curso superior de administração e finanças e o curso de atuário, de que trata o decreto $n^{\circ} 20.158$, de 30 de julho de 1931" (brasil, 1945, capítulo vi, art. $9^{\circ}$ ).

Assim, é possível compreender que ocorreu uma alteração na contribuição promovida pela reforma Francisco Campos. O último decreto mencionado tinha como objetivo: dispor "sobre o ensino superior de ciências econômicas e de 
ciências contábeis e atuariais" e, a partir daí, o curso de Administração perdia seu status, por não ter entrado no rol de graduações regulamentadas.

Com essa legislação, as disciplinas relacionadas ao ensino da área foram atribuídas aos cursos de Contabilidade. Por outro lado, conteúdos teóricos e quantitativos foram destinados aos cursos de Economia. Conforme Sanson e Nicolau (2006), essa divisão foi baseada nos moldes estadunidenses. Quanto a isso, Coelho (2006) ressaltou que antes desse decreto, o Ensino Superior de Administração era baseado no modelo europeu, que tinha como ênfase as Ciências Jurídicas. Com a nova determinação, a formação técnica em Administração passou a ter foco em técnica e práticas, tendo como objetivo o desenvolvimento pragmático. Conforme Paula (1991), esse foi um momento decisivo para a reorganização das faculdades que ministravam o curso de Administração e Finanças.

Nesse contexto, até 1945, São Paulo contava com três escolas com cerca de 500 bacharéis formados no curso superior de Ciências Econômicas (Scwartzmann, Bomeny, Costa, 1984). No Rio de Janeiro, em 1945/1946 é implementada a Faculdade Nacional de Política e Economia ${ }^{10}$ e firmada a incorporação da Faculdade de Ciências Econômicas e Administrativas do Rio de Janeiro ${ }^{11}$, de cunho privado. E, assim, tornou-se a primeira faculdade federal, agora denominada: Faculdade Nacional de Ciências Econômicas, a oferecer o Curso de Economia no Brasil por ter se vinculado à Universidade do Brasil (Scwartzmann, Bomeny, Costa, 1984). Esclarecemos que essa faculdade já havia sido prevista na reforma Francisco Campos, mais especificamente, na organização da Universidade do Rio de Janeiro.

O debate sobre a redemocratização na década de 1940 no País culminou em movimentos pela modernização do Ensino Superior, que deveria ser público, gratuito e de qualidade. Além disso, o acesso a ele deveria ser ampliado e planejado a serviço da sociedade. Tais ações contaram com o apoio da UNE (União Nacional dos Estudantes), que havia sido criada em 1937.

Mais precisamente em 1946, foi iniciado o movimento de democratização do Brasil. Assim, o voto popular direto levou o marechal Eurico Gaspar Dutra ao poder (1946-1951), o qual, com objetivos populistas, ofereceu apoio à união de educadores na Associação Brasileira de Educação (ABE) sob a liderança de Anísio Teixeira. Em 1946, são criados o Conselho Federal de Contabilidade e os conselhos regionais de contabilidade, por meio do Decreto-Lei 9.295 de 27 de maio de 1946, para a fiscalização das profissões de contador e guarda-livros.

Ainda, em 1946, é fundada a Faculdade de Administração, Economia e Contabilidade da USP - FEA. Em meio à ampliação do ensino no cenário nacional, em 1947 foi criado o Instituto Tecnológico de Aeronáutica (ITA), baseado nos padrões de qualidade do ensino aplicados nos Estados Unidos e influenciou mudanças nos rumos educacionais do Ensino Superior no Brasil.

Em 1948, representantes da Fundação Getúlio Vargas visitaram universidades estadunidenses que ofereciam o curso de Administração Pública, por meio do acordo de Cooperação Técnica Brasil-Estados Unidos. Naquele momento, eram percebidos sinais de avanços no desenvolvimento da pesquisa científica o Brasil, os quais também permitiram a criação do Conselho Nacional de Desenvolvimento Científico e Tecnológico (CNPq) e da Coordenação de Aperfeiçoamento de Pessoal de Nível Superior (CAPES), ambos em 1951. Um ano depois, a Escola Brasileira de Administração Pública (Ebap) também passou a ministrar cursos de treinamento nesse campo. Do mesmo modo, em 1951, a Fundação Getúlio Vargas havia iniciado cursos em Administração Púbica com suporte da ONU (Fischer, 1985).

À medida que o Brasil se desenvolvia economicamente, aumentava progressivamente o debate, as pressões $\mathrm{e}$ demandas por melhorias nas condições básicas para a maioria de seus habitantes. Uma das medidas adotadas para "acalmar os ânimos” foi a elaboração do Plano Saúde, Alimentação, Transporte e Energia (Salte), que vigorou de 1948 a 1951. Ele contou

\footnotetext{
${ }^{10}$ Criada, formalmente, em 1937, por meio da Lei 452 de 05 de julho de 1937, como pertencente à Universidade do Brasil.
}

${ }^{11}$ Criada em 1938. 
com o apoio dos Estados Unidos nas áreas mencionadas, e, como podemos perceber, a educação não estava incluída no campo deste planejamento.

É importante salientar que, por meio de acordos de cooperação entre Brasil e Estados Unidos, foi possível trazer professores e técnicos ao Brasil para a criação de cursos de Administração Pública (Fischer, 1985). Na década de 1950, também foi responsável por trazer os primeiros consultores e professores da área ao País, além de oferecer bolsas de estudos a brasileiros nos Estados Unidos.

Além disso, a partir da década de 1950, ocorreram inúmeras discussões sobre os rumos da educação no País, em especial por causa do modelo de desenvolvimento que excluía considerável parcela da população, devido aos interesses privatistas nos diálogos relativos à Educação Pública Brasileira. Dessa forma, surgiram mudanças relevantes no cenário educacional com a posse em 1951 de Anísio Teixeira para a função de diretor do Instituto Nacional de Estudos Pedagógicos (Inep).

Em 1951, é regulamentada a profissão de economista pela Lei Federal no 1411 de 13 de agosto de 1951 e assim foi consolidado o Curso de Ciências Econômicas. Em 1952, foi fundada a Escola Brasileira de Administração Pública e de Empresas da Fundação Getúlio Vargas (Ebape/FGV), no Rio de Janeiro. Em 1954, entrou nesse cenário a Escola de Administração de Empresas, da Fundação Getúlio Vargas (EAESP/FGV), em São Paulo.

Conforme Fischer (2001), antes da participação da Ebap/FGV de São Paulo e Rio de Janeiro no convênio PBA 1 (Project Agreement Between the International Cooperation Administration), o apoio era recebido pela ONU. Ele prevaleceu de 1951 a 1958, e era considerado um programa com amplitude maior, que também contemplava as duas outras faculdades: Ebap/FGV de São Paulo e Rio de Janeiro. A EAESP, como representante brasileira nessa situação, atuou no estabelecimento das diretrizes curriculares mínimas do curso de Administração. Em relação a isso, Taylor (1968) enfatiza que houve pouca margem para diálogo sobre a organização do curso entre a EAESP e as autoridades estadunidenses, por conta de imposições dessas últimas. Nessa mesma perspectiva, Alcadipani e Bertero (2012) e Taylor (1968) pontuam que os brasileiros eram vistos como atores secundários no processo de decisões. Inclusive, o título de docente era reservado aos estadunidenses, e aos brasileiros, o título de apoio técnico.

Em 1954, o Decreto n 1.401 de 31 de julho de 1954, decreta o desdobramento do Curso de Ciências Contábeis e Atuariais em Ciências Contábeis e de Ciências Atuariais. Em relação ao Curso de Administração, ele consolidou-se da seguinte forma:

Quadro 3: Cursos de nível superior na área de Administração entre 1941 a 1954.

\begin{tabular}{|l|c|c|c|l|}
\hline \multicolumn{1}{|c|}{ INSTITUIÇÃO } & SIGL & $\begin{array}{c}\text { DATA DE } \\
\text { FUNDAÇÃO }\end{array}$ & \multicolumn{1}{c|}{ OBSERVAÇÕES } \\
\hline $\begin{array}{l}\text { Escola Superior em Administração e } \\
\text { Negócios. }\end{array}$ & Esan & 1941 & $\begin{array}{l}\text { No início, não foi reconhecida } \\
\text { oficialmente. }\end{array}$ \\
\hline $\begin{array}{l}\text { Escola Brasileira de Administração Pública, } \\
\text { no Rio de Janeiro. }\end{array}$ & Ebap & 1952 & $\begin{array}{l}\text { Atual Fundação Getúlio Vargas, no } \\
\text { Rio de Janeiro. }\end{array}$ \\
\hline $\begin{array}{l}\text { Faculdade de Ciências Econômicas e } \\
\text { Administrativas de Minas Gerais, em Belo } \\
\text { Horizonte. }\end{array}$ & Face & 1941 & Atual UFMG \\
\hline $\begin{array}{l}\text { Escola Brasileira de Administração Pública e } \\
\text { de Empresas, em São Paulo. }\end{array}$ & PAES & 1954 & $\begin{array}{l}\text { Atual Fundação Getúlio Vargas, em } \\
\text { São Paulo. }\end{array}$ \\
\hline
\end{tabular}

Fonte: Machado (1966).

Mais adiante, ao tomar posse, Juscelino Kubistchek (1956-1961), diferentemente do Governo Vargas, que visava o desenvolvimento mais autônomo do Brasil, tinha um discurso voltado para a necessidade de equilibrar o investimento 
financeiro e a ação do Estado. Nesse novo período governamental do Brasil, ocorreram algumas mudanças, como, por exemplo, o desenvolvimento industrial nacional avançou, devido à articulação entre o Estado e os capitais nacional e internacional. A política industrial foi definida de forma a oferecer facilidades na implementação de medidas para o crescimento do Brasil (Suzigan, 1988).

Nesse processo, somente a partir de março de 1959, mediante solicitação do Ponto IV ${ }^{12}$, os cursos de Administração ganharam um novo impulso. Isso ocorreu após a assinatura de um acordo entre o Brasil e os Estados Unidos, com a disponibilização de recursos financeiros, custeamento de vinda de professores e envio de docentes para estudo e formação nos Estados Unidos.

Essa parceria se refere ao PBA (Project Agreement Between the International Cooperation Administration), firmado em 1959. Já os participantes desse convênio foram: o Ministério da Educação e Cultura, Departamento Administrativo do Serviço Público, Fundação Getúlio Vargas, Universidade Federal da Bahia e a Universidade Federal do Rio Grande do Sul. O governo estadunidense foi representado pelo Instituto de Assuntos Interamericanos e pela Missão Norte-Americana de Cooperação Técnica do Brasil (Usom). Esse acordo teve duração de 1959 a julho de 1965, enquanto a EAESP funcionou como apoio à criação de outras faculdades no cenário brasileiro. Assim, estavam lançadas as bases para a consolidação e expansão do ensino de Administração, que viria se juntar aos cursos de Ciências Contábeis e Ciências Econômicas relacionadas ao processo de expansão e interiorização pelo território brasileiro.

Nesta perspectiva, consideramos que as três formações estudadas neste artigo se caracterizam como verticalização do Ensino Comercial, isto, porque o mesmo foi oferecido na Educação Básica, na Educação Profissional e na Educação Superior. Ao longo do século XX a continuidade de estudos a nível superior do Ensino Comercial desenvolveu-se e delimitou-se no Brasil, influenciada pelo modelo estadunidense. Consideramos, ainda que a falta de definições precisas, em seus primórdios, fez com que o Ensino Comercial ao se verticalizar, perdesse significativamente seu espaço inclusive, no nível técnico com a criação dos cursos de Técnico em Contabilidade e Técnico em Administração.

\section{Considerações Finais}

Ressaltamos que a análise das origens e história do Ensino Comercial no Brasil, mostra algumas continuidades e rupturas em relação ao desenvolvimento dos cursos, pela representação de que naquele momento ainda não estavam claras as delimitações de cada um dos cursos analisados. Foi possível perceber algumas alterações nas denominações dos cursos, na atribuição dos títulos, alterações nas legislações, dentre outros fatores, os quais em conjunto representaram uma trajetória que se espelhou primeiramente no Ensino Comercial que era oferecido na Metrópole Portuguesa.

Posteriormente, com o advento da fase industrial, foram importados modelos de ensino empresariais estrangeiros. Esse momento foi crucial para que os cursos analisados alcançassem maior prestígio, a partir dos "investimentos" estadunidenses e melhor aceitação pelos estudantes brasileiros que buscavam uma profissão. Além disso, o foco pela Administração Pública para a gestão do período que se iniciava propiciou que o Curso de Administração, enquanto, o último dos três cursos superiores analisados a se consolidar no Brasil.

Outrossim, foi a trajetória pelos níveis de ensino, iniciando-se por Aulas, disciplinas inseridas em outros cursos, , Educação Profissional, Ensino Técnico e Ensino Superior. Foi uma longa trajetória que levou em conta a verticalização do ensino e mostrou jogos de interesses, muitas vezes, contraditórios pautados na valorização e incentivos a alguns cursos em

\footnotetext{
${ }^{12}$ Programa de cooperação técnica entre os Estados Unidos e os países latino-americanos. Foi o quarto ponto no discurso de posse do presidente estadunidense Harry Truman, e por isso recebeu o nome de Ponto IV. No Brasil, esse programa foi constituído por meio da assinatura de dois acordos: Acordo Básico de Cooperação Técnica em 19 de dezembro de 1950 e Acordo de Serviços Técnicos Especiais, em 30 de maio de 1953.
} 
detrimentos de outros a depender do momento. Ficou claro, ainda a interdependência e complementaridade entre os cursos analisados devido à proximidade teórica e metodológica dos cursos relacionados entre si.

Nesse contexto, esperamos que este artigo sobre as origens e evolução do Ensino Comercial permita uma melhor compreensão do conjunto de possíveis interpretações para as mudanças ocorridas neste contexto.

Enquanto sugestões para trabalhos futuros, sugerimos um estudo que analise a verticalização entre os cursos relacionados às ciências empresariais, na atualidade.

\section{Referências}

Alcadipani, R., \& Bertero, C. O. (2012). Guerra Fria e ensino do management no Brasil: o caso da FGV-EAESP. Revista de Administração de Empresas, 52(3), 284-299.

Aranha, M. L. de A. (1996). História da Educação. (2a ed.), revista e atual. Moderna.

Barros, A. N. de. (2013). Uma narrativa sobre a História dos Cursos de Administração da FACE-UFMG: às margens do mondo e à sombra da FGV? Centro de Pós-Graduação e Pesquisa em Administração. TESE. Belo Horizonte.

Bomfim, A. M., \& Roças, G. (2018). Educação superior e educação básica nos Institutos Federais: a verticalização e a capilaridade do ensino a partir da avaliação dos docentes. Revista Brasileira da Educação Profissional e Tecnológica v. 1 n.14 n. 6697.

Brasil. Decreto n ${ }^{\circ}$ 1.339, de 09 de Jan. de 1905. < http://www.camara.gov.br/sileg/integras/214141.pdf>.

Brasil. Lei $\mathrm{n}^{\mathrm{o}}$ 17.329, de 28 de maio de 1926. < http://www2.camara.leg.br/legin/fed/decret/1920-1929/decreto-17329-28- maio-1926-514068-republicacao88142-pe.html>.

Brasil. Decreto no 19.850 de 11 de abril de 1931a. <http://www2.camara.leg.br/legin/fed/decret/1930-1939/decreto-19850-11-abril-1931-515692publicacaooriginal-1-pe.html> .

BRASIL, 1931. Diário Oficial - 15/4/1931, Página 5800 (Publicação Original). Decreto $\mathrm{n}^{\circ} 19.851 \quad$ de 11 de abr. de $1931 \mathrm{~b} . \quad<$ http://www2.camara.leg.br/legin/fed/decret/1930-1939/decreto-19851-11-abril-1931-505837-publicacaooriginal-1-pe.html>.

Brasil. Decreto no 19.852 de 11 de abril de 1931c. Dispõe sobre a organização da Universidade do Rio de Janeiro. < http://www.planalto.gov.br/ccivil_03/decreto/1930-1949/D19852>.

Brasil. Decreto $\mathrm{n}^{\mathrm{o}}$ 20.158, de 30 de junho de 1931d. Organiza o ensino comercial, regulamenta a profissão de contador e dá outras providências. <http://www2.camara.leg.br/legin/fed/decret/1930-1939/decreto-20158-30-junho-1931-536778-republicacao-81246-pe.html>.

Brasil. Decreto no 1.155 de 19 de outubro de 1936. <http://www.planalto.gov.br/ccivil_03/decreto/1930-1949/D1.155.htm>.

Brasil. Decreto-Lei $\mathrm{n}^{\circ}$ 4.073, de 30 de janeiro de 1942. Lei orgânica do ensino industrial. Diário Oficial da União, Rio de Janeiro, seção 1, p. 1997, 9 fev. 1942 .

Brasil. Decreto-Lei n. ${ }^{\circ} 6.141$ - 28 dez. 1943. Lei Orgânica do Ensino Comercial. Diário Oficial do Distrito Federal, Rio de Janeiro, 31 dez. 1943.

Brasil, 1945 Decreto-Lei 20.068 de 30 de novembro de 1945 . Reconhece a confederação Nacional do Comércio. <https://www2.camara.leg.br/legin/fed/decret/1940-1949/decreto-20068-30-novembro-1945-480483>.

Caires, V. G., \& Oliveira, M. A. M. (2016). Educação Profissional Brasileira: da colônia ao PNE 2014-2024. Ed. Vozes.

Canabrava, A. P. (1984). “As condições sociais, econômicas e políticas da fundação”. CANABRAVA, A. P. (Org.) História da Faculdade de Economia e Administração da Universidade de São Paulo 1946/1981. FEA-USP.

Canabrava, A. P. (1985). Escolas de Comércio: A conquista da validade propedêutica. Revista Brasileira de Contabilidade. 55, $23-8$.

Cardoso, I. de A. R. (1982). A universidade da comunhão paulista. São Paulo: Autores Associados: Cortez (Coleção educação contemporânea). (Memória da Educação).

Cintra, E. P. de U. (2009). Cursos comerciais em colégio católico feminino: uma aparente contradição? 1940-1950. Educar. 33, 235 -252.

Coelho, F. de S. (2006). Educação Superior, Formação de Administradores e Setor Público: um estudo sobre o ensino de administração pública - em nível de graduação - no Brasil. Tese (Doutorado em Administração) - Escola de Administração de Empresas de São Paulo. São Paulo, 151 f.

Curi, L. M. (2018). Leis de Equivalência no Brasil. Curso de História da Educação Profissional e Tecnológica no Brasil - Disciplina de Mestrado - MPET (Mestrado Profissional em Educação Tecnológica do IFTM - Câmpus Uberaba). Abril. Notas de Aula.

Fernandes, M. R. da S. (2013). O processo de verticalização da educação profissional e tecnológica e suas implicações na qualidade do trabalho dos docentes do Câmpus São Vicente do Sul do Instituto Federal Farroupilha. 2013. [103 f.]. Dissertação (Programa de Pós-Graduação em Educação Agrícola) Universidade Federal Rural do Rio de Janeiro, [Seropédica - Rio de Janeiro].

Fischer, T. M. (1985). O ensino de administração pública no Brasil: da tutela estrangeira à autonomia necessária. In: Reunião nacional da Anpad, Belo Horizonte, 1985. Anais... Florianópolis-SC: 1985. Ed. da UFSC, 165-170. 
Research, Society and Development, v. 10, n. 12, e510101220314, 2021

(CC BY 4.0) | ISSN 2525-3409 | DOI: http://dx.doi.org/10.33448/rsd-v10i12.20314

Fischer, T. M. (2001). A difusão do conhecimento sobre organizações e gestão no Brasil: seis propostas para o decênio 2000/2010. Revista de Administração Contemporânea. Edição Especial, 123-129.

Franco, H. (1988). A Evolução dos Princípios Contábeis no Brasil, Atlas.

Leite, C. E. B. (2005). A evolução das Ciências Contábeis no Brasil. FGV.

Ludke, M., \& Andre, M. E. D. A. (2013). Pesquisas em educação: uma abordagem qualitativa. E.P.U.

Machado, M. B. (1966). O Ensino de Administração Pública no Brasil. Rio de Janeiro: Editora da Fundação Getúlio Vargas.

Masetto, M. T. (Org.). (1988). Docência na universidade. Papirus.

Oliven, A. C. (1992). Origem, características e desenvolvimento do sistema de ensino superior no Brasil. In: Morosini, M, Leite, D. Universidade e integração no Cone Sul. Ed. da Universidade, 89-94.

Paula, J. A. (1991). Passado e presente de uma Instituição: memória da Faculdade de Ciências Econômicas/UFMG. UFMG/FACE/CEDEPLAR.

Pedrosa, J. G., \& Santos, O. G. (2014). Agentes do Ensino Industrial no Brasil (1920-30-40) e suas referências internacionais. Cadernos de História da Educação, 13(1).

Quevedo, M. de. (2016). "Verticalização nos Institutos Federais de Educação, Ciência e Tecnologia: concepção(ões) e desafios no IFRS." Dissertação (Mestrado em Educação) - Programa de Pós-Graduação em Educação, Universidade Caxias do Sul. Rio Grande do Sul, 152 f.

Rôças, G., \& Bomfim, A. M. do. (2017). "Educação Superior e Educação Básica nos Institutos Federais: avaliação da verticalização de ensino com seus gestores." Revista Eletrônica Debates em Educação Científica e Tecnológica. 50-73.

Romanelli, O. de O. (2007). História da Educação no Brasil (1930/1973). Vozes.

Sampaio, H. (1991). A evolução do ensino superior brasileiro: 1888-1990. Documento de Trabalho, NUPES/USP, 8, 1-30. <http://nupps.usp.br/downloads/docs/dt9108.pdf>.

Sanson, J. R., \& Nicolau, J. A. (2006). Do ensino de técnicas comerciais ao ensino de economia em Santa Catarina. Análise, 17(2), 297-312

Schwartzman, S., Bomeny, H. M. B. \& Costa, V. M. R. (1984). Tempos de Capanema. Edusp/Paz e Terra, 219-225.

Schwartzman, S. (2005). Os desafios da educação no Brasil. Nova Fronteira.

Schmidt, P. (2000). História do Pensamento Contábil, Globo.

Silva, L. B. (1980). A contabilidade no Brasil: aspectos do desenvolvimento por influência da legislação e da contabilidade, São Paulo, 1980, Dissertação Faculdade de Economia, Administração e Contabilidade da Universidade de São Paulo.

Suzigan, W. (1988). Estado e Industrialização no Brasil. Revista de Economia Política, 08, 5-16.

Taylor, D. A. (1968). Institution building in business administration: the Brazilian experience. East Lansing: Michigan State University. 